\title{
THE SAWFLY GENUS AlLANTIDEA ROHWER (HYMENOPTERA: ALLANTINAE) IN INDIA
}

\author{
M.S. Saini and V. Vasu
}

Department of Zoology, Punjabi University, Patiala, Punjab 147002, India

\begin{abstract}
The genus Allantidea Rohwer is represented by one species viz. A. bengalensis (Cameron) in the Indian subcontinent. The taxonomic validity of this species has been supported by taxonomic redescription, illustrations, detailed discussion and review.
\end{abstract}

\section{KEYWordS}

Allantidea bengalensis, Allantinae, Hymenoptera, review

\section{AbBreviations}

EL - eye length ; IATS - inner apical tibial spur; ICD - inter cenchri distance; IDMO - interoocular distance at level of median ocellus; ITD - inter tegular distance; LID - lower interocular distance; MB - metabasitarus; NHM - National History Museum; NR - OATS - Outer apical tibial spur; OCL - oculooccipital line; OOL - oculoocellar line; POL postocellar line

Taxonomic studies on the sawfly genus Allantidea erected by Rohwer (1912) taking Monophadnus bengalensis Cameron as its type species were carried out from the Indian subcontinent. This genus restricted to the oriental region is represented only by its type species so far. The hosts plants of this species remain unknown. The species is redescribed following a standardized uniform pattern defined for the Allantine sawflies. This would help accommodating the new arrivals at ease if described under this genus in future. Illustrations pertaining to genitalia and other morphological characters of taxonomic importance are provided, however, the male genitalia has not been dissected out keeping in view the importance of the determined-material.

The species, Allantidea bengalensis, was first described by Cameron (1876) under the genus Monophadnus Hartig. It was later on shifted to the genus Eriocampa Hartig by Kirby (1882), but Konow (1905) transferred this species to the genus Taxonus Hartig while cataloguing the global Sawfly fauna. Later on Rohwer (1912) erected a new genus Allantidea taking Monophadnus bengalensis Cameron as its type, which ended the controversial status of the species. This status was accepted and retained by Malaise (1957), Abe and Smith (1991), and Koch (1996). Malaise (1957) also added a new species fumipennis to this genus from Myanmar, but Koch (1996) synonymized it with bengalensis Cameron.

\section{Genus Allantidea Rohwer}

Allantidea Rohwer, 1912: 208-209; Malaise, 1957: 14, 15; Abe \& Smith, 1991: 5, 102; Koch, 1996: 236.

Type species

Monophadnus bengalensis Cameron (original designation).

\section{Distribution}

Oriental region.

\section{Diagnosis}

Adult: Clypeus broad, short, arcuately incised; eyes converging; malar space indistinct; posterior orbits broad; antennae stout, nine segment, incrassated in middle, pedicel hardly longer than its apical width, segment three much longer than four; mandible with two prominent subapical teeth; propodeum divided along middle by long and narrow seam; scutellum not acute; tarsal claw with a large apical and shorter subapical teeth, basal lobe broad and triangular. Forewing without any appendiculate cell and hindwing with a rather large such cell; anal cell of forewing without any trace of contraction before base and its long cross-vein strongly oblique.

\section{Allantidea bengalensis (Cameron)}

Monophadnus bengalensis Cameron, 1876: 461; Abe \& Smith, 1991: 5.

Eriocampa bengalensis: Kirby, 1882: 185.

Taxonus bengalensis: Konow, 1905: 109.

Allantidea bengalensis: Rohwer, 1912: 209; Malaise, 1957: 14, 15, 16; Koch, 1996: 236-238.

Allantidea fumipennis Malaise, 1957: 14, 15; Koch, 1996: 236238.

\section{Material depository}

Holotype: Female (Monophadnus bengalensis Cameron), NHM, London; female (Allantidea fumipennis Malaise), NR, Stockholm.

Paratype: One male (Allantidea fumipennis Malaise), NR, Stockholm.

Determined specimens: One female, one male (Monophadnus bengalensis Cameron), det Malaise, NR, Stockholm.

\section{Material examined}

Holotype: (borrowed from NHM, London) appended with labels as: female, Monophadnus bengalensis Cameron, 1876, B.M. Type, HYM, 1.327, Allantidea bengalensis (Cameron), det. F. Koach, 195.

Determined specimens: (borrowed from NR, Stockholm) appended with labels as: Male Allantidea bengalensis (Cameron) det. Malaise, 1938, 28.ii.1934, 12/90, NR, Stockholm, N. Shan States, Maymyo, 1500m, coll. Malaise.

\section{Individual variation}

Both specimens alike 

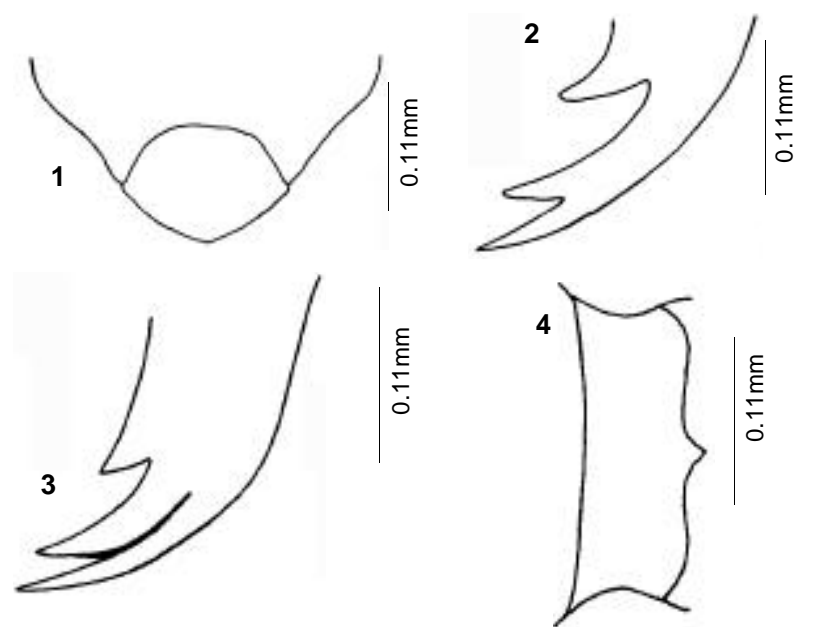

5

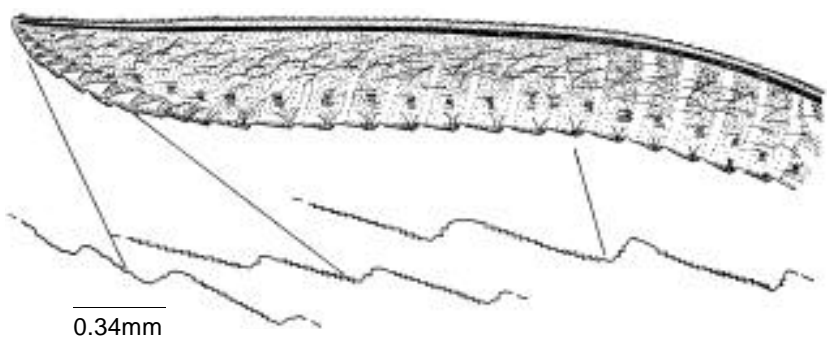

Figures 1-5. Allantidea bengalensis (Cameron) 1 - Clypeus and labrum; 2 - Mandible; 3 - Tarsal claw; 4 - Hypopygium; 5 - Lancet

\section{Distribution}

Myanmar, Bangladesh, India: West Bengal.

\section{Diagnostic features}

Based upon the following combination of characters such as: black colour with oily bluish reflection of the body; general pattern of distribution of punctures on various parts of body; distinctly marked furrows on head, longer than wide postocellar area, insignificant malar space; tarsal claw with laterally placed shorter subapical tooth and broadly triangular basal lobe; flat top of mesoscutellum with ecarinate appendage; antenna short, segment three longer than four; and infuscated apical half of forewing, the species dealt herein, viz., A. bengalensis (Cameron) makes up its real entity.

\section{Female:}

Colour: Body black with distinct oily bluish tinge, yellowish are: apical $1 / 2$ of coxae, entire trochanters, front four femora except posterior stripe along apical $1 / 3$, basal $2 / 3$ of metafemur, front four tibiae except posterior stripe on apical $2 / 3$, basal $1 / 4$ of metatibia. Forewing with infuscated apical half, hindwing clear, venation including costa, subcosta and stigma fuscous.

Structure: Length 9.0mm. Antenna 1.6x head width, scape longer than wide, pedicel as long as wide, segments three and four as 5:3; clypeus (Fig. 1) with pointed lateral teeth and roundly incised up to $3 / 5$ of its length, labrum (Fig. 1) broader than long as 5:3 with roundly pointed anterior margin; mandible threetoothed (Fig. 2); postgenal carina absent, hind orbits ecarinate; LID:IDMO:EL = 1.0:1.3:1.2, POL:OCL:OOL = 1.0:2.0:1.8; supraclypeal and supra-antennal pits well marked; frontal area below level of eyes, supra-antennal tubercles confluent with similar low lying frontal ridges; median fovea in form of broad, deep triangular depression; post-, inter- and circum-ocellar furrows distinct; lateral furrows shallow, bulging medially and ending abruptly just before hypothetical hind margin of head; postocellar area subconvex, longer than wide as 4:3; head narrowing behind eyes; mesoscutellum flat, appendage ecarinate; ICD:ITD = 1.0:4.0; tarsal claw (Fig. 3) with laterally placed subapical tooth stronger but shorter than apical one and distance between two tips distinctly shorter than length of subapical one, basal lobe distinct, triangularly tooth like; metabasitarsus distinctly shorter than following three joints combined as 3:4, IATS:MB:OATS = 1.0:4.5:0.9. Hypopygium as in Fig. 4. Lancet (Fig. 5) having 24 serrulae.

Sculpture: Head impunctate, shining; rest of body subshining with minute and sparsely distributed punctures.

Pubescence: Silvery, $0.3 x$ scape length.

Male: Length $8.5 \mathrm{~mm}$. Similar to female excepting entirely yellowish mesotibiae. Genitalia not dissected out.

\section{REFERENCES}

Abe, M. and D.R. Smith (1991). The genus-group names of Symphyta (Hymenoptera) and their type species. Esakia 31: 1-115.

Cameron, P. (1876). Descriptions of new genera and species of Tenthredinidae and Siricidae, chiefly from the East Indies, in the collection of the British Museum. Part III. Transactions of the Royal entomological Society of London, 1: 459-471.

Kirby, W.F. (1882). List of Hymenoptera with Descriptions And Figures of Typical Specimens in the British Museum, Vol. I. Tenthredinidae and Siricidae. Taylor and Francis, London, 8: 1-450, 16 pls.

Koch, F. (1996). Taxonomie, Phylogenie and verbreitung sgeschichte der tribus Xenapateini (Insecta: Hymenoptera: Tenthredinidae: Allantinae). Entomologhische Abhandlungen staatliches Museum fur Tierkunde Dresden 57(11): 225-260.

Konow, F.W. (1905). Hymenoptera, Fam. Tenthredinidae. In: P. Wytsman (Ed.) Genera Insectorum. Fasc. Brxelles, 29: 176pp.

Malaise, R. (1957). Some Neotropical and Oriental Tenthredinoidea (Hym.). Entomologisk Tidskrift 78: 6-22.

Rohwer, S.A. (1912). Notes on sawflies with description of new species, Smithsonian Institution Proceedings of the United States National Museum, Washington 43: 205-251.

\section{ACKNOWLEDGEMENTS}

The author is highly thankful to Prof. M.S. Saini, Department of Zoology, Punjabi University, Patiala, India for allowing the study and physical verification of the material of the species in question and also for this valuable suggestions.

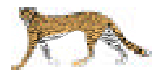

